\title{
Maternity Leave Legislation: The Timidity of the New Zealand Approach
}

\section{Alexander Szakats*}

This article examines in detail the Maternity Leave and Employment Protection Act 1980, and compares its benefits with corresponding British and West German legislation. The lack of maternity pay during leave is especially criticised in light of the reasonably generous overseas systems. Even the right to return to the previous job or preference in other comparable positions is shown to be fragile, while the formal requirements of giving notices and putting the complaints procedure into motion may prove too complex and cumbersome for a mother preoccupied with pregnancy, confinement and the care of a newborn baby. The father cannot help during the day as there is no provision for paternity leave.

The Maternity Leave and Employment Protection Act 1980, the Bill of which was introduced in 1979 despite sharp criticism expressed in submissions from many organisations to Parliament's Labour and Education Committee, has now become a statute. It may be of some interest to look at its purported protective measures and compare them with those of the corresponding British and German legislation.

\section{The New Zealand Statute}

The salient points of the Act will be examined in detail.

\section{Entitlement to leave without pay.}

A female employee who becomes pregnant and at the expected date of delivery has been employed by the same employer for the immediately preceding 18 months for at least 15 hours a week is entitled to maternity leave.(s5)

The leave is to be taken in one continuous period of 26 weeks (s8(1)) beginning

(a) on the date of confinement, (s9(a)) or

(b) on a date not earlier than 6 weeks before the expected date of delivery provided the employee gives 21 days notice in writing of the day she wishes to begin her leave, (s10(1)\&(2))

(c) on any date before the confinement as agreed between the employer and employee, (s11) or

(d) on a date specified by a written certificate of a registered medical practitioner. (s12(1))

The employee should give the medical certificate to the employer and her leave in such a case starts either on the date as specified or on the date of confinement whichever occurs earlier. (s12(2))

Where because of her pregnancy the employee cannot perform her work to the safety of herself and others, or becomes incapable of adequately performing it and no other suitable work is available, the employer may direct her to commence the leave on a date earlier than the expected date of delivery, even though the commencing date falls more than 6 weeks before the presumed day of delivery. (s13)

In such cases the female employee is entitled to take at least 20 weeks of her leave after the expected date of delivery, and if necessary the duration of the leave will be extended. (s8(2))

The employee must give written notice of her intention to take maternity leave accompanied by a medical certificate at least 3 months before the expected date of delivery. (s14) By a counternotice given within 21 days after receiving the female

* Professor Emeritus, University of Otago. See also in this issue the Research Note by M. Law.

1 Hereinafter quoted as "the Act". Section references in the text refer to the Act. 
employee's notice the employer is under a duty to state that the employee can take the leave, and also that her position either can or cannot be kept open. Where the advice is that her position cannot be kept open, the employer must inform the employee that:

(a) she may dispute this statement, and

(b) she will be given preference over other applicants for any position "which is vacant and which is substantially similar to the position held by her at the beginning of the maternity leave."

Note that the preference will be available only during a period of 26 weeks after the end of the leave, and is dependent on whether or not a substantially similar job will be vacant within the statutory period.

The employer's notice also must inform the employee of her rights and obligations under the Act. (s15)

The position is presumed to be kept open unless the employer proves that it cannot be kept open

(a) because a temporary replacement is not reasonably practicable due to the key position of the employee, or

(b) because a redundancy situation occurred.

Whether a position is a key one, the size of the enterprise and the training period or skill required in the job should be considered (s16)

\section{Return to work}

Within 21 days after the beginning of the leave the employer must give written notice of the date on which the leave will end, and if the position is kept open, state the date on which the employee is required to return to work, being the next working date after the end of the leave. If there is a mere promise for preferential employment, the notice should state the period of 26 weeks during which the preference applies. Her obligations under s18 and rights under s19 also should be included in the notice. (s17)

Section 18 provides that a female employee on leave should inform the employer not later than 21 days before the end of her leave whether or not she will be returning to work. Under section 19 she may choose to return to work or to take advantage of the preference of re-employment at an earlier date if

(a) she suffers miscarriage, or

(b) the child is stillborn or dies, or

(c) she has consented to the adoption of her child and some other person has custody with a view to adoption, or

(d) the employer consents.

The employer's consent may be conditional on a medical certificate of fitness.

If the female employee fails without good cause to return to work at the end of the leave or informs the employer to that effect, then "her employment shall... be deemed to have been at an end," as from the beginning of her maternity leave. (s29) The same consequences follow if a position offered in preference of other applicants is not accepted without reasonable excuse on the date specified or within 7 days after that date. (s21)

Upon return to work or upon re-employment her service "for the purpose of any rights and benefits that are conditional on unbroken service, shall not be broken". (s22) This statutory reassurance is most gratifying but in the case of returning to her former position the maternity leave should not be regarded as terminating the employment, as she carries on working under the original contract of service. If she has been offered a position in place of her previous job, however, she enters into a new contract and the statutory provision is necessary to preserve her rights. Any superannuation contributions have to be continued during the leave, otherwise that period will not be counted. (s23) 
During the period of pregnancy where by reason of the pregnancy, the female employee is unable to perform her work to the safety of herself or others or is incapable of doing her work adequately, the employer may temporarily transfer her to another job. (s24) A pregnant employee may before her maternity leave take 10 days special leave without pay for reasons connected with the pregnancy. (s25)

The Act expressly states that the employer of a female employee who is granted maternity leave is not obliged to pay any remuneration for this period. (s7) Nor is there any maternity benefit payable under the Social Security Act 1964, as a matter of right distinct from emergency benefits, domestic purposes benefits or family benefits. ${ }^{2}$ The maternity benefits provided by that Act are not monetary ones but relate to hospital and medical treatment. ${ }^{3}$ Their importance cannot be denied, but in overseas systems direct payments are made to the female employee while away from work because of childbirth. ${ }^{4}$

\section{Prohibition of dismissal and maternity leave complaints}

It is a praiseworthy feature of the legislation that termination of employment by reason of pregnancy or state of health connected with pregnancy or taking maternity leave, is prohibited except with the consent of the female employee, or unless she absents herself from work without medical certificate or without the employer's approval for more than 6 weeks before the expected date of delivery. (s27) Dismissal for a substantial reason not related to her pregnancy or her rights under the Act, nevertheless, remains within the employer's rights. (s32) Redundancy payments which may be payable under any statute, order, instrument, or agreement or contract of employment are not affected under the Act. (s31)

Where a female employee is dismissed in contravention of the Act she may apply to the Arbitration Court, within two months, for an interim order of reinstatement or cancellation of the notice of termination. The application will be heard by a Judge alone. The interim order remains in force for 26 weeks only, or for 20 weeks after the date of delivery, but it may be renewed if the Court is satisfied that the employee is taking steps to use the maternity leave complaints procedures available to her. (s33) These processes closely resemble the grievance machinery, which pursuant to s117 of the Industrial Relations Act 1973 is included or is deemed to be included in every collective instrument. The Act, however, expressly declares that a maternity leave complaint is not a personal grievance and the grievance procedure should not be used for dealing with it. (s34(4))

A maternity leave complaint should be made within 26 weeks after the cause of it arose, or within 20 weeks before the expected date of delivery, whichever is the later, if the employee claims that her employer

(a) is not justified in stating in the notice given to her that her position cannot be kept open, or

(b) has terminated or given notice to terminate the employment in contravention of the Act, or

(c) has taken other action that affects to her disadvantage her rights and benefits in respect of maternity leave, or

(d) has exercised without justification

(i) the power of directing her to commence maternity leave at an early date on the grounds of safety or incapability, or

(ii) the power to transfer her to another job on the same grounds. (s34(1)\&(2))

2 Social Security Act 1964, as amended, s 61; ss 27A - 27H; ss 32 - 39.

3 Social Security Act, ss $106-115$.

4 See Parts 2 and 3 of this article. 


\section{Complaints procedure and remedies}

The first step is to submit the complaint to the immediate supervisor so that the cause of it could be remedied and the matter settled rapidly.(s35(1)\&(2)) If this attempt is not successful, the employee has to notify the appropriate union representative, or if she does not belong to a union an Inspector of Award (s38) or may instruct a barrister or solicitor or any agent to act for her. ${ }^{5}(\mathrm{~s} 35(3))$ Nothing prevents, nevertheless, the employee acting on her own behalf. (s34(4)\&s37) In any case, unless the matter is amicably settled by discussions between the representatives of the employee and the employer, a written statement must be prepared setting out the facts, establishing the nature of the complaint and of the issues. (s35(5)) A complaint committee should be formed consisting of equal number of representatives, not more than three, of the parties with a chairman as agreed or if the parties fail to agree, a conciliator or mediator. (s36) When the employee acts for herself the committee will comprise of herself and the employer with a chairman appointed in the same manner. (s37)

In case the complaint cannot be dealt with or dealt with promptly, because any other person failed to act in accordance with the procedure, the employee with the leave of the Arbitration Court may refer the matter direct to that Court. (s43) ${ }^{6}$

An employee in complaint proceedings merely has to prove that the employer, either during her absence on maternity leave or during the period of 26 weeks beginning with the day after the date on which her leave ended, terminated her employment. As there is a statutory presumption that the employer can keep open the employee's position during the maternity leave, (s16) the burden of proof to the contrary is on the employer. In defence he may prove (s28)

(1) When the dismissal occurred during maternity leave that

(a) a temporary replacement was not reasonably practicable due to the key position of the employee, and

(b) a redundancy situation occurred and that there was no prospect to appoint her to a similar position, and

(c) her seniority or superannuation rights were not prejudicially affected. (s29)

(2) Where the dismissal occurred during the 26 weeks period beginning with the day after the end of the leave

(a) the same matters as in (b) or (c) above, and

(b) that the employer had been unable to appoint her to a vacant position similar to that held at the beginning of her leave. (s30)

The Committee reaches its decision by majority but in case of equal division the chairman can either decide alone, and this will be the decision of the Committee, or refer the complaint to the Arbitration Court. (s39) Appeal against the decision of the Committee may be lodged with the Court within 14 days after the decision came to the knowledge of the appellant by giving written notice of appeal within a further 7 days with the Registrar of the Court. (s40) Remedies available are reimbursement, compensation and reinstatement which can
be granted separately or together. (s42) Whether or not relief is granted the Court may
impose a penalty not impose a penalty not exceeding $\$ 500$ on the employer. The penalty goes into the Consolidated Account but the Court may make an order that the whole or part of it is
to be paid to the employee. (s45)

\section{The position of State employees}

The legislation expressly declares that the term "employee" includes a State employee, which in turn means every person whose remuneration is determined by an
employing authority or tribunal under the State Services Conditions of Employment

\footnotetext{
5 Where there is no union to which the employee could have belonged, an inspector may act as agent.
6 Note the resemblance to 117 (3A) of the Industrial Relations Act.
} 
Act 1977, Hospitals Act 1957, Post Office Act 1959, Police Act 1968, Education Act 1964 or by the Higher Salaries Commission. (s2) As a result the maternity leave provisions and the prohibition of dismissal apply to all State servants in the same manner as to employees in the private sector.

It is to be noted, however, that the remedies provided by the Act, that is, application for an interim order of reinstatement and the maternity complaint procedure are not available to State employees, as the relevant sections specially exclude them.' Section 47, however, declares that "nothing in this Act shall limit the procedures by which State employees may enforce their conditions of employment and those procedures may be used, where appropriate, to enforce the rights conferred ... by this Act".

The effect of these provisions is that the Public Sector Tribunal or the particular single service tribunals, that is the Government Service Tribunal, the Government Railways Industrial Tribunal, the Hospital Service Tribunal, the Police Staff Tribunal and the Post Office Staff Tribunal have jurisdiction in maternity complaints of persons belonging to these services. In case of the education service the Primary Teachers' Appointment Appeal Board ${ }^{8}$ and the Teachers Court of Appeal ${ }^{9}$ have important functions, but it seems doubtful that even if their jurisdiction would extend to maternity leave complaints they could grant the remedies of reimbursements, compensation and reinstatement. The same doubt may.be expressed in respect of all the public sector tribunals, notwithstanding that their chairman is one of the Judges of the Arbitration Court ${ }^{10}$. Unless the jurisdiction of all these tribunals is substantially broadened to include the settling of maternity leave complaints exactly in the same manner as the Arbitration Court, with power to grant the same remedies, female employees of the State Services remain in a position inferior to those of their sisters working in private employment.

\section{Further features of the Act}

The protective measures in the Act may be regarded as merely setting a minimum standard. The Act expressly provides that if any award, agreement or contract of employment stipulates for rights and benefits in respect of maternity leave more favourable to the female employee than those in the statute the more favourable provisions will prevail. (s4)

A further noteworthy and novel feature of the Act is that the protective measures are extended, with the necessary alterations, to female employees who assume the care of a child under the age of 5 years with a view to adoption. ${ }^{12}$

Reference may also be made to the Human Rights Commission Act 1977 which expressly declares that preferential treatment granted by reason of a woman's pregnancy or childbirth will not constitute unlawful discrimination and a breach under that Act. ${ }^{13}$

At this juncture it also should be pointed out that a temporary employee replacing a female employee on maternity leave must be advised in writing before being employed that the employment is on temporary basis during the permanent employee's absence only and that the employee on leave may return earlier than the date required. (s26) The purpose of this provision is to negative any possible claim for wrongful or unjustified dismissal by the temporary worker. It seems that such an employee may be dismissed at short notice, or without any notice at all.

7 ss 33 and 34 contain the words " (not being a State employee)".

8 Education Act 1964, s 114.

9 Ibid., s 174.

10 State Services Conditions of Employment Act 1977, ss 37, 49, 50, 51; Post Office Act 1959, ss 200 - 202 , 205; Police Act 1968, ss 67, 68, 81 .

11 But note the provisions of s 31A of State Services Act (as amended 1978) regarding reappointment after absence for child care purposes.

12 See ss 6, 9(a), 10 (1)(b), 14 (2), 19 (1)b, 27 (1)(a)(iv), 34 (27)(b)(ii).

13 Human Rights Commission Act, s 30. 


\section{The British Legislation}

The latest British ${ }^{14}$ corresponding legislation is contained in the Employment Protection (Consolidation) Act 1978 and the Employment Act 1980. The New Zealand statute is modelled to some extent on the 1978 Statute, but a brief comparison will show that the more favourable features have been omitted.

The most significant differences are that in Britain an employee absenting herself from work because of pregnancy or confinement is entitled

(a) to return to her job after 29 weeks' absence, and

(b) to receive maternity pay from the employer. $(\mathrm{s} 33(1))^{15}$

Whether or not a contract of employment subsists during the absence does not make any difference, but there are certain prerequisites, and the employee will not be entitled to these rights unless

(a) she continues to be employed by her employer until immediately before the beginning of the eleventh week before the expected day of confinement, (whether or not actually working);

(b) she has at the beginning of the eleventh week been continuously employed for at least 2 years; and,

(c) she informs the employer, in writing if so requested, at least 21 days before her absence begins or as soon as reasonably practicable that

(ii) she will be or is absent from work because of pregnancy or confinement, and

(ii) she intends to return to work, if there is such a right. (s33(3))

An employee who has been dismissed for pregnancy and has not been re-engaged (s60) retains her rights to return to work and also to maternity pay whether the dismissal is fair or unfair. (s33(4) $)^{16}$

The right to return to work shall be exercised by written notice and confirmation to return $^{17}$ at any time before the end of the 29 weeks period beginning with the week in which the confinement falls. The employer or his successor is under a statutory duty to give back to the emplyee the job in which she was employed under the original contract of employment on terms and conditions not less favourable than those which would have been applicable if she had not been absent, including seniority, pension rights and other similar rights. (s45(i)) The period of employment before the absence is to be regarded as continuous with the employment after the absence. (s45(2)) If the employer has five or less employees and it is not practicable to give back the previous position or provide another suitable one, he is relieved of the obligation to reinstate. Where reinstatement is not reasonably practicable for other reasons she will be entitled to alternative employment but only if a suitable vacancy occurs. (s45(3)) ${ }^{18}$ The new contract of employment must provide for work which is both suitable in relation to the employee and appropriate for her to do in the circumstances; further, it must contain terms and conditions as to capacity and the place of work "not substantially less favourable" than if she had returned to her original position. (s45(4)) It seems that even though returning to her previous job upon the same terms and conditions, her contract would be regarded as a new one, but the statutory provision for continuity of employment saves her accumulated rights. Some contracts of employment, nevertheless, expressly reserve a right to return and in such case the employee may
exercise the more favourable right. (s48)

14 The word "British" is used as the Act extends to the whole of the United Kingdom. 15 Employment Protection (Consolidation) Act 1978 (UK). Section references in Part 2 refer to this Act.

17 Employment Act 1980, s 11.

18 As modified by Employment Act 1980, s 12. 
Failure to make an offer of a similar position is automatically to be treated as an unfair dismissal. Refusing an offer of alternative employment on less favourable terms by the returning employee will not be regarded as unreasonable, but the employer is likely to be acting unreasonably and unfairly. ${ }^{19}$

Time off must not be unreasonably refused for the purposes of receiving ante-natal care, and the appropriate remuneration is payable. ${ }^{20}$

The most remarkable advantage of the British Act over the New Zealand one lies in the entitlement to maternity pay. It is payable for a period of not more than 6 weeks during the absence because of pregnancy or confinement at a rate of nine-tenths of a week's pay reduced by the amount of maternity allowance received under the Social Security Act 1975. (s34(1)\&s35(1)) It accrues on a day to day basis. (s35(2)) Since 1977 employees receive an earning related supplement in addition to maternity allowance. Only the flat rate allowance will be deducted from the amount to be paid by the employer, and as a result the female employees practically receive full pay during the period of 6 weeks. ${ }^{21}$ There is no entitlement to maternity pay for any absence before the beginning of the eleventh week preceding the expected week of confinement and the payment period will be the first six weeks of absence starting on or falling after the beginning of that eleventh week. (s34(2))

Contractual remuneration payable to an employee will go towards discharging the employer's liability in respect of maternity pay and similarly the other way round. (s35(4))

A Maternity Pay Fund has been established and the employer has the right to claim refund for any amount paid by him, as maternity pay rebate. If the employee claims that her employer is liable to pay and she has taken all reasonable steps to recover or the employer has become insolvent, the fund may pay the unpaid maternity pay direct to her, provided the Secretary of State is satisfied that the claim is well founded. (ss3740)

Failure of the employer to give the maternity pay can be remedied through a complaint presented to an industrial tribunal. The employee should lodge her complaint before the end of a period of three months beginning with the last day of the payment period or periods, otherwise the tribunal will not entertain it. The time, however, may be extended. Where the tribunal finds the complaint well founded, it will order the employer to pay the amount due. (s36) In disputes relating to right of return and dismissal also the industrial tribunals have jurisdiction. $(\mathrm{s} 60)^{22}$

\section{The German Mother Protection Act}

The German statutory provisions relating to maternity benefits are contained in the Mother Protection Act $1968^{23}$ and the Federal Social Insurance Regulations ${ }^{24}$ which should be considered together as they are complementary. The legislation provides for a protection period connected with pregnancy and childbirth, regulates the kind of work a female employee who is becoming or is a mother may perform, and prohibits dismissal.

Expectant mothers in employment in order to get the special protection must notify their employer of their pregnancy and the probable date of delivery. If the employer requests it, a certificate from a medical practitioner or midwife should verify the notice. The notice creates a protection period which covers the duration of pregnancy, childbirth and nursing of the child. (s5)

19 Sched. 2, para 2 (2); see also Hepple, para 2 - 1844.

20 Employment Act 1980, s 13; in case of non-payment complaint lies to an Industrial Tribunal.

21 Hepple, para 2 - 1834.

22 Hepple, para 2 - 1864; see also para 2 - 1848.

23 Mutterschutzgesetz, 18 April 1968, with later amendments, BGBI, 1, S.875, Fed. Republic of Germany/Beck-Texte, Munich. Text references are to this Act.

24 Reichsversicherungsordnung, 15 Dec 1924, with later amendments, RGBI I.S.779, Fed. Republic of Germany; Beck-Texte, Munich. 
Pregnant women must not work, if a medical certificate indicates that the work would endanger the life or health of the mother or child. In the last 6 weeks of the pregnancy they are not allowed to work at all. (s3).In general, expectant mothers are prohibited from performing heavy physical tasks or any job involving close contact with dangerous materials, chemicals or where they are exposed to heat, extreme cold, smoke, steam, dampness, noise or vibration. (s4(1)) Types of occupation involving certain tasks or movements are specially listed as forbidden:

(a) Lifting weights;

(b) Standing after 5 months pregnancy;

(c) Frequent bending, stretching, squatting or stooping;

(d) Handling appliances or machines with foot control;

(e) Contact with woodshaving;

(f) Where an occupational disese may develop;

(g) After 3 months of pregnancy working in transportation;

(h) Working at height where there is a danger of slipping and falling. (s4(2))

Piecework and assembly line work is also prohibited. (s4(3))

After confinement women may not work for 8 weeks, and in case of premature or multiple birth for 12 weeks. (s6) Following that period nursing mothers can do light work, but they should be given twice a day one half hour for feedint the baby. The nursing time does not count as part of the ordinary rest period. (s7)

There is a general prohibition both for expectant and nursing mothers to work overtime at night between $8 \mathrm{pm}$ and $6 \mathrm{am}$ or on holidays, but in special circumstances exemptions can be made. ( $(\mathrm{s} 8)$

Dismissal during pregnancy and four months after confinement is not permissible and it will be invalid, if the employer knew of the woman's condition or within two weeks after giving notice he was informed. (s9) This provision, however, does not preclude a woman during the pregnancy or the protection period after confinement from terminating her employment. (s10)

As far as benefits are concerned most women who are employed or whose employment has been validly terminated during the pregnancy will receive maternity money from Social Insurance funds, if between the 10th and 4th months before confinement they were in employment or covered by Social Insurance at least for 12 weeks. ${ }^{25}$ Women who are not entitled to maternity money must be paid by the employer at least the average of the last 3 months or 13 weeks wages earned before the pregnancy. (s11) To mothers receiving maternity money the employers must pay the difference between that money and their average remuneration earned while at work. (s14) The extra allowances are tax free. (s17)

In addition the legislation provides for free medical and midwifery services before and after delivery including hospital or home services. (s15) Further, the employer must allow free time for any kind of medical examination in connection with motherhood without any deduction from remuneration. $(\mathrm{s} 16)^{26}$

\section{Which is the Best System?}

None of three systems is perfect and each of them has shortcomings, but it can be said without exaggeration that the New Zealand legislation offers the least protection. It allows 26 weeks unpaid leave as against the right to return within 29 weeks in Britain. In Germany the compulsory leave period covers 6 weeks before the delivery the 4 months following delivery is prohibited, confinemment, but as dismissal during 
half months or 23 weeks. Thus, the British leave provisions appear to be the most generous.

It should not be forgotten, nevertheless, that the right to return to work both in the United Kingdom and here is a fragile right which can be displaced leaving the female worker with a complaint before the tribunal. Furthermore, even though the right can be exercised, its actual value for a mother who has to look after a young child is questionable. Without access to childcare facilities or adequate home help, for all practical purposes it is impossible to reclaim the job previously held and the legal right will lapse. The German Act provding for light work upon return and time off for nursing seems to be more realistic.

The greatest weakness of the New Zealand law lies in the complete lack of providing any monetary benefits for the working mother either in form of a Social Welfare payment or continuation of wages. Can a mother while off work during the 26 weeks apply for unemployment benefit? Most likely not, especially if she has a working husband! Nothing prevents the employer, of course, from paying her during the absence when he is willing or the contract so provides, but the statute does not compel him to do so. In contrast, both in Britain and in Germany the female employee is entitled in addition, or instead of, Social Welfare maternity benefit to payment of part of her wages with the result that she receives about the same amount as when she was at work.

A further drawback of the legislation in New Zealand is the requirement of formal notices in order to exercise the rights. When a pregnant female wishes to take leave she must give a formal written notice 3 months before the expected date of delivery. Later, if she wants to return to work she has to notify the employer at least 21 days before the end of the leave. Fortunately, there is no requirement for a written notice in case she decides not to return to work and it appears that no formality is necessary to take up employment within 7 days after it has been offered. Still, a woman approaching her time of confinement and afterwards being left busy with an infant has enough worry on her mind without the further trouble of remembering the statutory period for notices. In any case, giving written notices may be a routine task for the employer, but for a woman who worked in a factory before her maternity leave, it can be a difficult job. Her trade union through the secretary or a special representative, however, probably will take care of the women on leave and will ensure that all the formal requirements are promptly complied with. The assistance of the trade union will also be necessary, if she intends to lodge a maternity leave complaint or to apply for an interim order, although an Inspector or a lawyer may also represent her.

Another omission from the Act is the lack of a provision for paternity leave to cover fathers who because of the wife's confinement and hospitalisation have to stay home to look after the older children. Submissions were made in this respect during the Bill stage of the statute, but obviously without persuading the Committee that the father's role in a responsible society goes much further than the act of insemination.

The conclusion cannot be other than that the protection giveen by the New Zealand legislation does not measure up to the benefits available to English and German working mothers. It amounts to a mere possibility - not a probability, let alone a firm right - to be re-employed after 26 weeks, if the job or a similar job is available. The statute appears to grant a protection which might prove to be illusory, like the fairy tale gift which the hero was commanded to give, and not to give, to the king. He solved this impossible demand by presenting a bird which immediately flew away.

\section{References}

Hepple, B. and P. O'Higgins (1980) Encyclopedia of labour relations law London, Sweet and Maxwell. (looseleaf).

Schmidt, F. (1978) Discrimination in employment Stockholm, Almqvist and Wiskell International. 